\title{
Antimicrobial activity and chemical components of two plants, Artemisia capillaris and Artemisia iwayomogi, used as Korean herbal Injin
}

\author{
Kyoung Sun Seo ${ }^{1}$, Hyung Jin Jeong ${ }^{2}$ and Kyeong Won Yun ${ }^{3, *}$ \\ ${ }^{1}$ ShinHung Pharmaceutical Co., Yeosu 550-230, Korea \\ ${ }^{2}$ Major of Medicinal Plant Resources, Andong National University, Andong 760-749, Korea \\ ${ }^{3}$ Department of Oriental Medicine Resources, Sunchon National University, Suncheon 540-742, Korea
}

This study compared the antimicrobial activity and chemical composition of two plants used as "Injin" (Korean herbal medicine), namely, Injinho (Artemisia capillaris Thunberg) and Haninjin (Artemisia iwayomogi Kitamura). The ethyl acetate and ether fractions of crude methanol extracts from A. capillaris and A. iwayomogi were tested against three grampositive bacteria (Bacillus cereus, Bacillus subtilis, Staphylococcus aureus), two gram-negative bacteria (Escherichia coli, Pseudomonas fluorescens), and a yeast (Saccharomyceus cerevisiae). The antimicrobial activity of the ethyl acetate and ether fraction of both plants was strong, but that of A. iwayomogi extracts was higher than that of A. capillaris extract for the microbes tested. The minimum inhibitory concentration of the ether and ethyl acetate fraction of A. iwayomogi was highest for $P$. fluorescens and lowest for $S$. aureus and $E$. coli. We analyzed the chemical composition of the ethyl acetate fraction of A. capillaris and A. iwayomogi using gas chromatography-mass spectrometry. The main components of $A$. capillaris and A. iwayomogi were escoparone (86.82\%) and scopoletin (20.47\%), respectively.

Key words: antimicrobial activity, Artemisia capillaris, Artemisia iwayomogi, escoparone, scopoletin

\section{INTRODUCTION}

Allelopathy is defined as any direct or indirect harmful effect of a plant on another organism (including microorganisms) through production of chemical (Rice 1984). Secondary metabolites may function in plant defense via allelopathic processes (Fernandez et al. 2009).

In recent years, there has been increasing interest in healthy lifestyles and healthy aging. As a result, many people are involved in searches for natural compounds that can improve health, especially those of plant origins. A great number of aromatic, spicy, medicinal, and other plants belonging to the family Asteraceae contain chemical compounds exhibiting antimicrobial and antioxidant properties (Boussaada et al. 2008). Antimicrobial and antioxidative plant oils and extracts have been used for many purposes, including raw and processed food preservation, pharmaceuticals, alternative medicines, and natural therapies (Hammer et al. 1999). Natural products are perceived as having fewer negative impacts than synthetic agents; natural products may be effective, selective, biodegradable, and less toxic to the environment. The genus Artemisia is one of the most important genera in the family Asteraceae and is widespread throughout the world. About 30 species in this genus are found in Korea. Members of this genus have a characteristic scent or taste, and are of botanical and pharmaceutical (c) This is an Open Access article distributed under the terms of the Creative Commons Attribution Non-Commercial License (http://creativecommons.org/licenses/by-nc/3.0/) which permits unrestricted non-commercial use, distribution, and reproduction in any medium, provided the original work is properly cited.
Received 26 December 2009, Accepted 2 February 2010

"Corresponding Author

E-mail: ykw@sunchon.ac.kr

Tel: +82-61-750-3664 Fax: +82-61-750-3660 
interest (Kordali et al. 2006) because they contain active polyphenolic compounds (Schmidt et al. 2007). Aromatic Artemisia plants are used as spices and in folk remedies as antiseptics. For example, powdered leaves of A. absinthium, A. biennis, A. frigida, and A. ludoviciana have been applied externally in salves and washes by native North Americans to treat sores and wounds and internally to treat chest infections (Kershaw 2000). Though A. capillaris and A. iwayomogi are considered weeds, the plants have been used in traditional medicine in Korea as Injin. A. capillaris is a common perennial herb and has been cultivated for use as a treatment for hepatitis in Korea. A. capillaris has antifungal effects (Choi et al. 2005) and allelopathic effects (Kil 1999), stimulates immune activities in human cells, and has anticancer activity (Lee et al. 2004). The major active components of $A$. capillaris are scoparone and capillarisin, and the concentrations of these compounds are related to the season of harvest (Choi et al. 2007). A. iwayomogi is a unique shrub of the genus in Korea. It inhibits hepatotoxicity and liver cirrhosis (Song et al. 2001) and has antioxidant activity (Kim et al. 1997) as well as antitumor and immunomodulating activity (Koo et al. 1994). The aim of this study was to compare the antimicrobial activity and major components of A. capillaris and A. iwayomogi.

\section{MATERIALS AND METHODS}

\section{Plant material}

The aerial parts of A. capillaris and A. iwayomogi were collected from a cultivated population in the Jinan Medicinal Herbs Experiment Station, Jeollabuk-do Agricultural Research \& Extension Services $\left(35^{\circ} 46^{\prime} 15^{\prime \prime} \mathrm{N}, 127^{\circ} 22^{\prime} 40^{\prime \prime}\right.$ E), Korea in June 2007. The leaves were air-dried for 12-14 days after collection for antimicrobical activity tests and chemical analysis.

\section{Microorganisms}

The test microorganisms included three gram-positive bacteria (Bacillus cereus ATCC 27348, Bacillus subtilis ATCC 9327 and Staphylococcus aureus ATCC 13301), two gram-negative bacteria (Escherichia coli ATCC 15489 and Pseudomonas fluorescens ATCC 11250), and one yeast (Saccharomyces cerevisiae IFO 1950). The gram-positive and gram-negative bacteria were cultured on a nutrient broth agar, while the yeast was cultured on yeast malt broth agar.

\section{Extract preparation for antimicrobial activity of two Artemisia plants}

We soaked $200 \mathrm{~g}$ samples of air-dried leaves of A. capillaris and A. iwayomogi in 1,000 $\mathrm{mL}$ of methanol and ground the mixture for 20 minutes. The solution was kept at room temperature for 30 minutes and then filtered through Whatman No. 2 paper.

The crude methanol extract was partitioned with 500 $\mathrm{mL}$ of hexane and then the top layer was concentrated (comprising the hexane fraction). The remaining layer was successively fractionated with $500 \mathrm{~mL}$ of diethyl ether and then ethyl acetate (forming the ether and ethyl acetate fractions). The remaining residue was the water fraction. Each fraction was concentrated in vacuo to 30 $\mathrm{mL}$ at $30^{\circ} \mathrm{C}$ and tested for antimicrobial activity. Antimicrobial activity was measured only with the ether fraction and the ethyl acetate fraction.

\section{Determination of antimicrobial activity}

Each bacterial strain was grown in a nutrient broth at $30^{\circ} \mathrm{C}$ for $18-24$ hours prior to testing and subcultured three times for another 18-24 hours. The turbidity of bacterial cell suspensions was brought to 0.3 optimal density (OD) at $660 \mathrm{~nm}$ by adding sterile broth and was then used for the tests. We poured $0.1 \mathrm{~mL}$ of the bacterial cell suspensions uniformly on nutrient broth agar plates. The paper disks containing the extracts (ether fraction and ethyl acetate fraction) were carefully placed on the seeded Petri dishes. The diameters of the resulting inhibition zones were measured in $\mathrm{mm}$ after the cultures were incubated at $30^{\circ} \mathrm{C}$ for 24 hours or 48 hours (Bauer et al. 1966). The antimicrobial activity was calculated as the net zone of inhibition estimated from the growth inhibition zone measurements (Mahasneh and El-Oqlah 1999). The minimum inhibitory concentration (MIC) was determined as the lowest concentration that caused an inhibition zone. We measured the inhibition caused by $0.1,0.25,0.5,1.0$, $1.5,2.0$, and $3.0 \mathrm{mg} / \mathrm{mL}$ extracts.

\section{Gas chromatography-mass spectrometry (GC- MS)}

The ethyl acetate fractions of A. capillaris and A. iwayomogi leaf extracts were analyzed by GC-MS using a GCMSD, equipped with an Ultra 2 (Crosslinked 5\% PH ME Siloxane, $25 \mathrm{~m}$ length $\times 0.20 \mathrm{~mm}$ i.d. Hewlett Packard, Palo Alto, CA, USA) with helium as a carrier gas at a constant flow rate of $1.0 \mathrm{~mL} / \mathrm{min}$. One $\mu \mathrm{L}$ of the extract was 
injected into the column using the split injection mode with a 10:1 split ratio. The oven temperature was initially held at $100^{\circ} \mathrm{C}$, then raised to $280^{\circ} \mathrm{C}$ at a rate of $3^{\circ} \mathrm{C} / \mathrm{min}$ for 50 minutes, and finally held at $280^{\circ} \mathrm{C}$ for 5 minutes. The temperatures of the injector and detector were $200^{\circ} \mathrm{C}$ and $240^{\circ} \mathrm{C}$, respectively. The mass detector was operated in the electron impact mode with an ionization energy of $70 \mathrm{eV}$, a scanning range of 33-550 a.m.u., and a scan rate of 1.4 scans/s. Components of the extracts were identified using the Wiley 275 Imass spectral database (HewlettPackard, 1995) or by manual interpretation. Glutaric acid was used as an internal standard for quantification.

\section{Data analysis}

We used a randomized complete block design with four replications in all experiments. Each experiment was repeated three or four times. Statistical analysis was conducted using the software program SPSS ver. 10.0 (SPSS Inc., Chicago, IL, USA). Comparisons between treatments were made at the 0.05 level using Duncan's multiple-range test.

\section{RESULTS AND DISCUSSION}

\section{Antimicrobial activity of the two Artemisia plants}

Local people use different plant parts to prepare phytomedicines, and the most frequently used parts are aerial parts, including leaves, fruits, seeds, and flowers (Kültür 2007). The antimicrobial activity and MIC of the ether and ethyl acetate fractions of methanol extract from the two Artemisia plants are shown in Tables 1 and 2. In general, A. iwayomogi exhibited stronger antimicrobial activity than A. capillaris, and the ethyl acetate

Table 1. Antimicrobial activity of the ether fraction of methanol extracts from Artemisia capillaris and Artemisia iwayomogi"

\begin{tabular}{|c|c|c|c|c|c|c|c|c|}
\hline & \multicolumn{7}{|c|}{ Clear zone $( \pm \mathrm{SD}, \mathrm{mm})$ at various concentrations $(\mathrm{mg} / \mathrm{mL})$} & \multirow{2}{*}{$\underset{(\mathrm{mg} / \mathrm{mL})}{\mathrm{MIC}}$} \\
\hline & 0.10 & 0.25 & 0.50 & 1.00 & 1.50 & 2.00 & 3.00 & \\
\hline \multicolumn{9}{|l|}{ Bacillus cereus } \\
\hline A. capillaris & $-{ }^{\dagger}$ & - & - & - & $8.3 \pm 0.1^{\mathrm{b}}$ & $8.7 \pm 0.2^{\mathrm{ab}}$ & $9.5 \pm 0.1^{\mathrm{a}}$ & 1.5 \\
\hline A. iwayomogi & - & - & $8.8 \pm 0.1^{\mathrm{d}}$ & $9.6 \pm 0.1^{\mathrm{d}}$ & $11.1 \pm 0.1^{\mathrm{c}}$ & $12.1 \pm 0.1^{\mathrm{b}}$ & $14.1 \pm 0.1^{\mathrm{a}}$ & 0.5 \\
\hline \multicolumn{9}{|c|}{ Bacillus subtilis } \\
\hline A. capillaris & - & - & $8.3 \pm 0.1^{\mathrm{c}}$ & $8.9 \pm 0.4^{\mathrm{bc}}$ & $9.4 \pm 0.2^{\mathrm{b}}$ & $9.7 \pm 0.1^{\mathrm{b}}$ & $11.1 \pm 0.1^{\mathrm{a}}$ & 0.5 \\
\hline A. iwayomogi & - & - & - & $9.3 \pm 0.5^{\mathrm{c}}$ & $12.1 \pm 0.4^{\mathrm{b}}$ & $12.8 \pm 0.6^{\mathrm{b}}$ & $14.0 \pm 0.4^{\mathrm{a}}$ & 1.0 \\
\hline \multicolumn{9}{|c|}{ Staphylococcus aureus } \\
\hline A. capillaris & - & - & - & - & - & $8.1 \pm 0.1^{\mathrm{a}}$ & $9.4 \pm 0.2^{\mathrm{a}}$ & 2.0 \\
\hline A. iwayomogi & - & - & - & $8.5 \pm 0.1^{\mathrm{c}}$ & $10.3 \pm 0.2^{\mathrm{b}}$ & $11.3 \pm 0.3^{\mathrm{a}}$ & $11.9 \pm 0.1^{\mathrm{a}}$ & 1.0 \\
\hline \multicolumn{9}{|c|}{ Escherichia coli } \\
\hline A. capillaris & - & - & - & - & $8.4 \pm 0.2^{\mathrm{b}}$ & $9.1 \pm 0.1^{\mathrm{b}}$ & $10.2 \pm 0.2^{\mathrm{a}}$ & 1.5 \\
\hline A. iwayomogi & - & - & - & $8.6 \pm 0.1^{\mathrm{c}}$ & $9.4 \pm 0.2^{\mathrm{c}}$ & $10.8 \pm 0.8^{\mathrm{b}}$ & $12.4 \pm 0.6^{\mathrm{a}}$ & 1.0 \\
\hline \multicolumn{9}{|c|}{ Pseudomonas fluorescens } \\
\hline A. capillaris & - & - & - & - & - & - & $8.6 \pm 0.2^{\mathrm{a}}$ & 3.0 \\
\hline A. iwayomogi & - & - & - & - & - & - & $8.6 \pm 0.1^{\mathrm{a}}$ & 3.0 \\
\hline \multicolumn{9}{|c|}{ Saccharomyces cerevisiae } \\
\hline A. capillaris & - & - & - & $8.7 \pm 0.1^{\mathrm{c}}$ & $9.3 \pm 0.1^{\mathrm{bc}}$ & $9.8 \pm 0.1^{\mathrm{b}}$ & $11.1 \pm 0.1^{\mathrm{a}}$ & 1.0 \\
\hline A. iwayomogi & - & - & - & - & $8.8 \pm 0.0^{\mathrm{a}}$ & $9.1 \pm 0.1^{\mathrm{a}}$ & $9.3 \pm 0.1^{\mathrm{a}}$ & 1.5 \\
\hline
\end{tabular}

SD, standard deviation; MIC, minimum inhibitory concentration.

"Means with the same letters within a row are not significantly different at $P=0.05$, according to Duncan's multiple range test.

${ }^{\dagger}$ Means are not detected. 
fraction showed stronger antimicrobial activity than the ether fraction (Tables 1 and 2). The diameters of the clear zones resulting from application of the ethyl acetate fraction ranged from $8.8 \mathrm{~mm}$ to $19.9 \mathrm{~mm}$ (including the diameter of the disk, $8.0 \mathrm{~mm}$ ). We classified the antimicrobial activity of the plant extracts into three classes as follows: weak (<10 mm inhibition zone), moderate (10$15 \mathrm{~mm}$ inhibition zone), and good to very good ( $>15 \mathrm{~mm}$ inhibition zone) (Mahasneh 2002).

Some gram-negative bacteria are less sensitive than other microbes to the action of plant extracts and compounds (Boussaada et al. 2008, Yun et al. 2008), but gramnegative bacteria are often more susceptible than grampositive bacteria to the inhibitory effects of essential oils (Smith-Palmer et al. 1998). In our study, the ether and ethyl acetate fractions of the plant extracts were more active against gram-positive bacteria than gram-negative bacteria and yeast: the antimicrobial action of the ethyl acetate fraction of A. iwayomogi was good to very good against all three gram-positive bacteria. Similar results have been reported other species in the family Asteraceae (e.g., Boussaada et al. 2008, Yun et al. 2008). B. subtilis was the microorganism with the lowest MIC value, indicating that it was the most sensitive to the antimicrobial properties of the plant extracts. Other sensitive microorganisms included B. cereus and E. coli, S. cerevisiae (yeast) exhibited higher sensitivity to the A. capillaris fractions than the A. iwayomogi fractions. Yeast is also resistant to the action of several other plant extracts (Seo et al. 2008).

\section{The chemical composition}

The ethyl acetate fraction of extracts of A. capillaris and A. iwayomogi leaves with a yield of $0.39 \%$ and $1.00 \%$, respectively. The chemical compositions of the ethyl acetate fractions of A. capillaris and A. iwayomogi are sum-

Table 2. Antimicrobial activity of the ethyl acetate fraction of methanol extract from Artemisia capillaris and Artemisia iwayomogi"

\begin{tabular}{|c|c|c|c|c|c|c|c|c|}
\hline & \multicolumn{7}{|c|}{ Clear zone $( \pm \mathrm{SD}, \mathrm{mm})$ at various concentrations $(\mathrm{mg} / \mathrm{mL})$} & \multirow{2}{*}{$\underset{(\mathrm{mg} / \mathrm{mL}}{\mathrm{MIC}}$} \\
\hline & 0.10 & 0.25 & 0.50 & 1.00 & 1.50 & 2.00 & 3.00 & \\
\hline \multicolumn{9}{|l|}{ Bacillus cereus } \\
\hline A. capillaris & $--^{\dagger}$ & - & - & $9.4 \pm 0.6^{\mathrm{b}}$ & $9.7 \pm 0.1^{\mathrm{ab}}$ & $10.2 \pm 0.3^{\mathrm{a}}$ & $10.7 \pm 0.3^{\mathrm{a}}$ & 1.0 \\
\hline A. iwayomogi & - & $9.8 \pm 0.4^{\mathrm{e}}$ & $12.8 \pm 0.4^{\mathrm{d}}$ & $16.2 \pm 0.4^{\mathrm{c}}$ & $17.1 \pm 0.4^{\mathrm{bc}}$ & $17.7 \pm 0.3^{\mathrm{bc}}$ & $18.3 \pm 0.6^{\mathrm{a}}$ & 0.25 \\
\hline \multicolumn{9}{|c|}{ Bacillus subtilis } \\
\hline A. capillaris & - & - & $9.0 \pm 0.1^{\mathrm{c}}$ & $9.7 \pm 0.7^{\mathrm{bc}}$ & $10.0 \pm 1.7^{\mathrm{ab}}$ & $10.6 \pm 1.6^{\mathrm{ab}}$ & $11.5 \pm 1.7^{\mathrm{a}}$ & 0.5 \\
\hline A. iwayomogi & - & $9.0 \pm 1.1^{\mathrm{e}}$ & $13.6 \pm 0.2^{\mathrm{d}}$ & $16.5 \pm 1.9^{c}$ & $17.3 \pm 1.5^{\mathrm{c}}$ & $18.3 \pm 1.1^{\mathrm{b}}$ & $19.9 \pm 0.6^{\mathrm{a}}$ & 0.25 \\
\hline \multicolumn{9}{|c|}{ Staphylococcus aureus } \\
\hline A. capillaris & - & - & - & $8.3 \pm 0.1^{\mathrm{a}}$ & $8.6 \pm 0.1^{\mathrm{a}}$ & $9.1 \pm 0.1^{\mathrm{a}}$ & $9.6 \pm 0.1^{\mathrm{a}}$ & 1.0 \\
\hline A. iwayomogi & - & $8.6 \pm 0.1^{\mathrm{e}}$ & $11.2 \pm 0.4^{\mathrm{d}}$ & $13.2 \pm 0.5^{\mathrm{c}}$ & $14.2 \pm 0.4^{\mathrm{b}}$ & $15.2 \pm 1.0^{\mathrm{a}}$ & $16.1 \pm 0.2^{\mathrm{a}}$ & 0.25 \\
\hline \multicolumn{9}{|c|}{ Escherichia coli } \\
\hline A. capillaris & - & - & - & - & $8.4 \pm 0.1^{\mathrm{b}}$ & $9.2 \pm 0.2^{\mathrm{ab}}$ & $9.6 \pm 0.1^{\mathrm{a}}$ & 1.5 \\
\hline A. iwayomogi & - & $8.8 \pm 0.9^{\mathrm{f}}$ & $11.1 \pm 2.4^{\mathrm{e}}$ & $12.9 \pm 3.1^{\mathrm{d}}$ & $14.4 \pm 3.0^{\mathrm{c}}$ & $16.1 \pm 2.9^{\mathrm{b}}$ & $17.9 \pm 2.5^{\mathrm{a}}$ & 0.25 \\
\hline \multicolumn{9}{|c|}{ Pseudomonas fluorescens } \\
\hline A. capillaris & - & - & - & - & $9.1 \pm 0.1^{\mathrm{b}}$ & $9.4 \pm 0.2^{\mathrm{b}}$ & $10.5 \pm 0.1^{\mathrm{a}}$ & 1.5 \\
\hline A. iwayomogi & - & - & - & - & - & $8.8 \pm 0.1^{\mathrm{a}}$ & $9.7 \pm 0.3^{\mathrm{a}}$ & 2.0 \\
\hline \multicolumn{9}{|c|}{ Saccharomyces cerevisiae } \\
\hline A. capillaris & - & - & - & $8.6 \pm 0.1^{\mathrm{b}}$ & $9.0 \pm 0.3^{\mathrm{b}}$ & $9.4 \pm 0.4^{\mathrm{b}}$ & $10.5 \pm 1.1^{\mathrm{a}}$ & 1.0 \\
\hline A. iwayomogi & - & - & - & $9.0 \pm 0.4^{\mathrm{b}}$ & $9.8 \pm 0.4^{\mathrm{b}}$ & $10.5 \pm 1.0^{\mathrm{ab}}$ & $10.9 \pm 1.1^{\mathrm{a}}$ & 1.0 \\
\hline
\end{tabular}

SD, standard deviation; MIC, minimum inhibitory concentration.

"Means with the same letters within a row are not significantly different at $P=0.05$, according to Duncan's multiple range test.

${ }^{\dagger}$ Means are not detected. 
marized in Figs. 1 and 2. The main component of the $A$. capillaris extract was escoparone (86.82\%). Escoparone may contribute to the anti-inflammatory activity of $A$. capillaris (Jang et al. 2005). The main component of $A$. iwayomogi was scopoletin (20.47\%). Escoparone, scopoletin, and isofraxidin, which were identified in extracts of both Artemisia plants are phenolic compounds, while achillin, identified in the extract of A. iwayomogi, is a sesquiterpene lactone. Escoparone and scopoletin, the major phenolic constituents of the two Artemisia plants, may contribute to their antimicrobial activity. The differences identified in the chemical components of the two Artemisia plants are likely responsible for at least some of the differences in their antimicrobial activity. Our results should encourage more in-depth studies of the antimicrobial activity of the individual chemicals identified in the two Artemisia plants.

Most phenolics that display antimicrobial activity are phenolic acids or flavonoids. Phenolic acids are a major class of phenolic compounds occurring in a diverse range of plants (Wojdyło et al. 2007), and the phenolic moiety plays an important role in determining a plant's antimicrobial activity (Kujumgiev et al. 1993). And mixtures of phenolic acids and other organic compounds can cause inhibitory effects even when the concentrations of the individual compounds are well below inhibitory levels (Blum 1996).

Our results provide the first detailed documentation of the in vitro antimicrobial features of two Artemisia species used as Korean herbal Injin. The antimicrobial compounds in Artemisia plants may have potential for use as safe and eco-friendly bactericides.

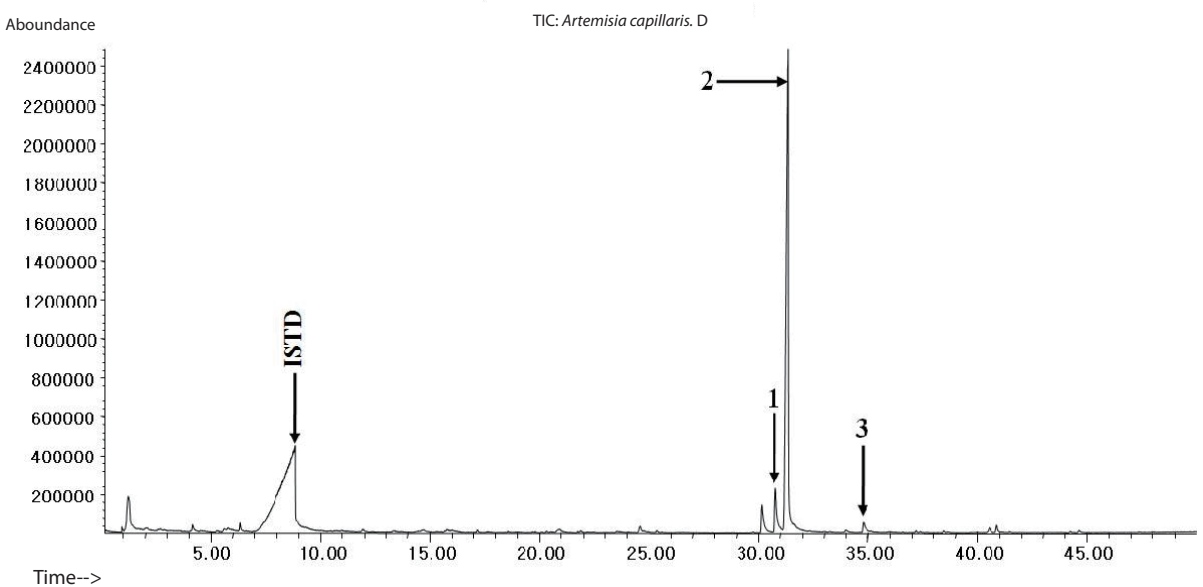

\begin{tabular}{clcccc}
\hline No. & Chemical name & Peak area/ISTD area & \% Area & MW & MF \\
\hline 1 & Scopoletin & 0.08 & 3.24 & 192.04 & C10H8O4 \\
2 & Escoparone & 0.88 & 86.82 & 206.06 & C11H10O4 \\
3 & Isofraxidin & 0.02 & 0.85 & 222.05 & C11H10O5 \\
\hline
\end{tabular}
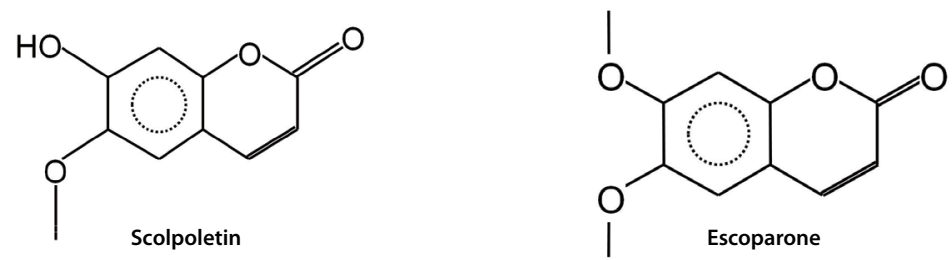

Fig. 1. GC chromatogram of the ethyl acetate fraction of an extract of Artemisia capillaris leaves and its components. GC, gas chromatography; ISTD, internal standard; $\mathrm{MW}$, molecular weight; MF, molecular formula. 


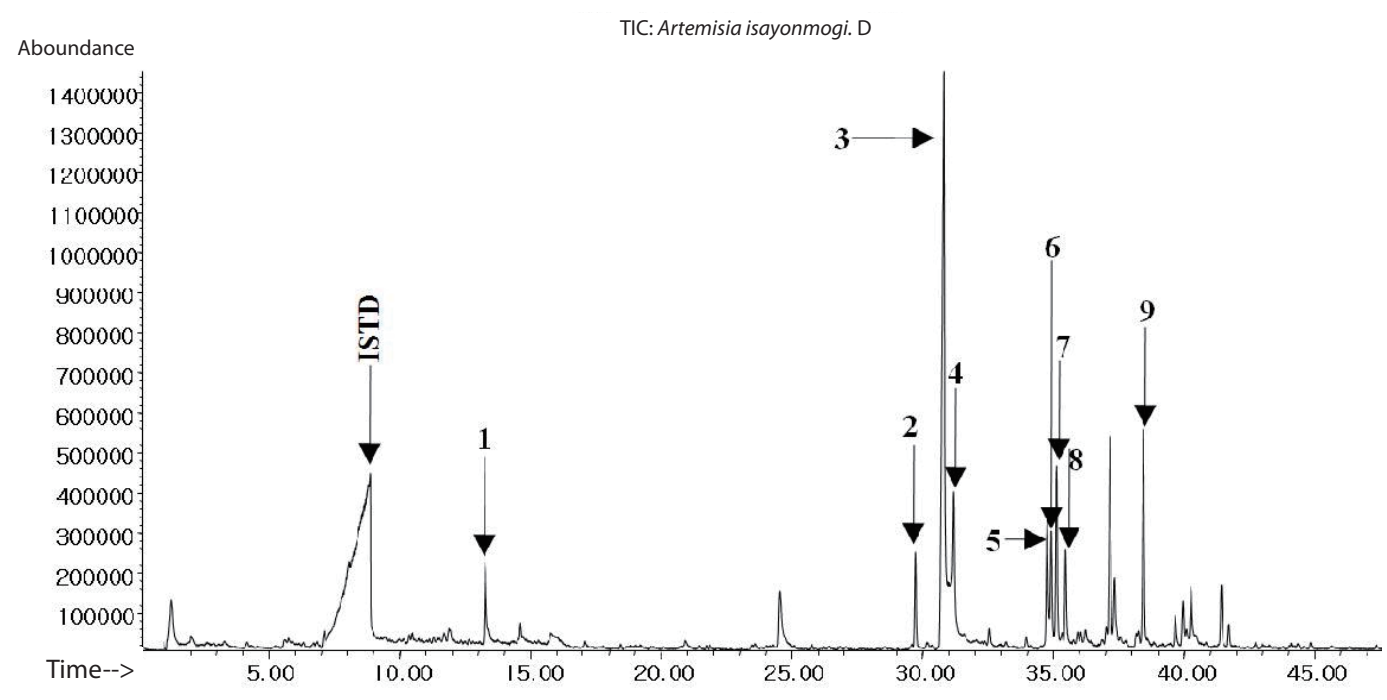

\begin{tabular}{rlcrrrr}
\hline No. & Chemical name & Peak area/ISTD area & \% Area & MW & MF \\
\hline 1 & Coumarin & 0.08 & 2.13 & 146.04 & C9H6O2 \\
2 & Palmitic acid & 0.07 & 1.87 & 270.26 & C17H34O2 \\
3 & Scopoletin & 0.79 & 20.47 & 192.04 & C10H8O4 \\
4 & Escoparone & 0.20 & 5.06 & 206.06 & $\mathrm{C} 11 \mathrm{H} 10 \mathrm{O} 4$ \\
5 & Isofraxidin & 0.13 & 3.44 & 222.05 & $\mathrm{C} 11 \mathrm{H} 10 \mathrm{O} 5$ \\
6 & Linoleic acid & 0.10 & 2.47 & 294.26 & $\mathrm{C} 19 \mathrm{H} 34 \mathrm{O} 2$ \\
7 & Linolenic acid & 0.14 & 3.66 & 294.24 & $\mathrm{C} 19 \mathrm{H} 32 \mathrm{O} 2$ \\
8 & Neophytadiene & 0.08 & 2.02 & 278.30 & $\mathrm{C} 20 \mathrm{H} 38$ \\
9 & Achillin & 0.19 & 4.83 & 246.13 & $\mathrm{C} 15 \mathrm{H} 18 \mathrm{O} 3$ \\
\hline
\end{tabular}<smiles>O=C1CCc2ccccc2O1</smiles><smiles>COc1cc2c(cc1O)OC(=O)CC2</smiles><smiles>CC1CCC2C(C)C(=O)OC2C2C(=O)CC(C)C12</smiles><smiles>COC(=O)CCCCCCCCCCCCC(C)C</smiles>

Palmitic acid<smiles>COc1cc2c(cc1OC)OC(=O)CC2</smiles>

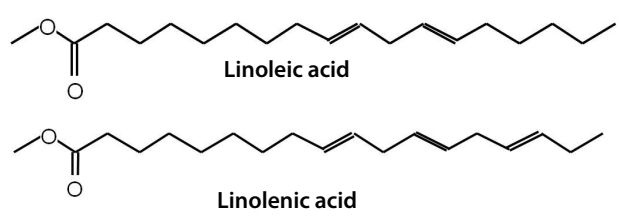

Fig. 2. GC chromatogram of ethyl acetate fraction of an extract of Artemisia iwayomogi leaves and its components. GC, gas chromatography; ISTD, internal standard; MW, molecular weight; MF, molecular formula. 


\section{ACKNOWLEDGMENTS}

This work was supported by the Korean Research Foundation Grant funded by the Korean Government (KRF-2007-521-F00012).

\section{LITERATURE CITED}

Bauer AW, Kirby WM, Sherris JC, Turck M. 1966. Antibiotic susceptibility testing by a standardized single disk method. Am J Clin Pathol 45: 493-496.

Blum U. 1996. Allelopathic interactions involving phenolic acids. J Nematol 28: 259-267.

Boussaada O, Chriaa J, Nabil R, Ammar S, Saidana D, Mahjoub MA, Chraeif I, Helal AN, Mighri Z. 2008. Antimicrobial and antioxidant activities of methanol extracts of Evax pygmaea (Asteraceae) growing wild in Tunisia. World J Microbiol Biotechnol 24: 1289-1296.

Choi IH, Kim YH, Lee DN, Kim HJ. 2005. Antifungal effects of Cinamon Ramulus, Pulsatillae Radix, Dictamni Radicis Cortex, Paeoniae Radix, Arecae Semen, Artemisiae Capillaries Herba against Candida albicans. Korean J Oriental Physiol Pathol 19: 690-695.

Choi SR, Ju IO, You DH, Song YE, Jang I, Ryu J. 2007. Changes of major components and growth characteristics according to harvesting times of Artemisia capillaris Thunberg. Korean J Medicinal Crop Sci 15: 189-193.

Fernandez C, Monnier Y, Ormeño E, Baldy V, Greff S, Pasqualini V, Mévy JP, Bousquet-Mélou A. 2009. Variations in allelochemical composition of leachates of different organs and maturity stages of Pinus halepensis. J Chem Ecol 35: 970-979.

Hammer KA, Carson CF, Riley TV. 1999. Antimicrobial activity of essential oils and other plant extracts. J Appl Microbiol 86: 985-990.

Jang SI, Kim YJ, Lee WY, Kwak KC, Baek SH, Kwak GB, Yun YG, Kwon TO, Chung HT, Chai KY. 2005. Scoparone from Artemisia capillaris inhibits the release of inflammatory mediators in RAW 264.7 cells upon stimulation cells by Interferon- $\gamma$ Plus LPS. Arch Pharm Res 28: 203-208.

Kershaw L. 2000. Edible and Medicinal Plants of the Rockies. Lone Pine Publishing, Edmonton, AB.

Kil BS. 1999. Allelopathic effects of Artemisia capillaris on the selected species. Korean J Ecol 22: 59-63.

Kim SS, Lee CK, Kang SS, Jung HA, Choi JS. 1997. Chlorogenic acid, an antioxidant principle from the aerial parts of Artemisia iwayomogi that acts on 1,1-diphenyl-2-picryl- hydrazyl radical. Arch Pharm Res 20: 148-154.

Koo KA, Kwak JH, Lee KR, Zee OP, Woo ER, Park HK, Youn HJ. 1994. Antitumor and immunomodulating activities of the polysaccharide fractions from Artemisia selengensis and Artemisia iwayomogi. Arch Pharm Res 17: 371-374.

Kordali S, Aslan I, Calmasur O, Cakir A. 2006. Toxicity of essential oils isolated from three Artemisia species and some of their major components to granary weevil, Sitophilus granaries (L.) (Coleoptera: Curculionidae). Ind Crops Prod 23: 162-170.

Kujumgiev A, Bankova V, Ignatova A, Popov S. 1993. Antibacterial activity of propolis, some of its components and their analogs. Pharmazie 48: 785-786.

Kültür S. 2007. Medicinal plants used in Kirklareli Province (Turkey). J Ethnopharmacol 111: 341-364.

Lee MK, Choi GP, Ryu LH, Lee GY, Yu CY, Lee HY. 2004. Enhanced immune activity and cytotoxicity of Artemisia capillaris Thunb. extracts against human cell lines. Korean J Medicinal Crop Sci 12: 36-42.

Mahasneh AM. 2002. Screening of some indigenous Qatari medicinal plants for antimicrobial activity. Phytother Res 16: 751-753.

Mahasneh AM, El-Oqlah AA. 1999. Antimicrobial activity of extracts of herbal plants used in the traditional medicine of Jordan. J Ethnopharmacol 64: 271-276.

Rice EL. 1984. Allelopathy. Academic Press, New York, NY.

Schmidt BM, Ribnicky DM, Lipsky PE, Raskin I. 2007. Revisiting the ancient concept of botanical therapeutics. Nat Chem Biol 3: 360-366.

Seo KS, Huh CK, Kim YD. 2008. Changes of biologically active components in Prunus mume fruit. Korean J Food Preserv 15: 269-273.

Smith-Palmer A, Stewart J, Fyfe L. 1998. Antimicrobial properties of plant essential oils and essences against five important food-borne pathogens. Lett Appl Microbiol 26: 118-122.

Song YE, Ryu JS, Chung JR, Kwak JS, Kim DH, Kim BS, Rim CW. 2001. Study on the biological activity of Artemisia iwayomogi Kitamura. Korean J Medicinal Crop Sci 9: 116-123.

Wojdyło A, Oszmiański J, Czemerys R. 2007. Antioxidant activity and phenolic compounds in 32 selected herbs. Food Chem 105: 940-949.

Yun KW, Jeong HJ, Kim JH. 2008. The influence of growth season on the antimicrobial and antioxidative activity in Artemisia princeps var. orientalis. Ind Crops Prod 27: 69-74. 